\title{
Benthic macroinvertebrate community structure and seasonal variation in a neotropical stream in the State of Alagoas, Brazil
}

\author{
Marden Seabra Linares ${ }^{1,2,3}$, Gregorio Guirado Faccioli ${ }^{2}$ \& Liriane Monte Freitas $^{1}$ \\ ${ }^{I}$ Natural History Museum - MHN, Federal University of Alagoas - UFAL, \\ CEP 57051-090, Maceió, AL, Brazil \\ ${ }^{2}$ Program of Development and Environment - PRODEMA, Federal University of Sergipe - UFS, \\ CEP 49100-000, São Cristóvão, SE, Brazil \\ ${ }^{3}$ Corresponding author: Marden Seabra Linares, e-mail:mslx@hotmail.com
}

LINARES, M.S., FACCIOLI, G.G. \& FREITAS, L.M. Benthic macroinvertebrate community structure and seasonal variation in a neotropical stream in the State of Alagoas, Brazil. Biota Neotrop. 13(3): http://www. biotaneotropica.org.br/v13n3/en/abstract?article+bn01013032013

Abstract: This paper presents a study on the macrobenthic community in the Salvia stream, a headwater stream that runs through a conserved Atlantic forest fragment in the state of Alagoas, Brazil, and identifies the environmental factors that most influence the community structure. Ten sampling sites were chosen, conducting each collection during the rainy season of 2010 and the dry season of 2011. At each site the macroinvertebrates were collected using a D net $(0.250 \mathrm{~mm}$ mesh). Water samples were collected and taken to the laboratory to analyze Dissolved Oxygen, Conductivity, $\mathrm{pH}$ and Alkalinity. Water temperature, surface current speed and depth were measured at the site. Canonical Correspondence was used to analyze the effect of environmental factors on the macroinvertebrate community. All the environmental factors measured showed significant variation between seasons, showing the seasonality effects on the stream environment. Eighteen taxa were identified, with predominance of Palaemonidae (Decapoda) and Chironomidae (Diptera), respectively, during the rainy and dry season. The results showed that the macroinvertebrates were more correlated to $\mathrm{pH}$, Alkalinity and Dissolved Oxygen, indicating that this ecosystem variation is mainly based on the organic matter decomposition process.

Keywords: aquatic insects; diversity; environmental factors; lotic environment; zoobenthic fauna.

LINARES, M.S., FACCIOLI, G.G. \& FREITAS, L.M. Estrutura da comunidade de macroinvertebrados bentônicos e suas variações sazonais em um riacho neotropical no estado de Alagoas, Brasil. Biota Neotrop. 13(3): http://www.biotaneotropica.org.br/v13n3/pt/abstract?article+bn01013032013

Resumo: O objetivo deste estudo foi descrever a comunidade macrobentônica do riacho da Salvia, um riacho de cabeceira que atravessa um fragmento conservado de floresta remanescente de Mata Atlântica, identificando os fatores ambientais que mais influenciam a estrutura da comunidade. Dez estações de coleta foram escolhidas, onde foram realizadas coletas durante a estação chuvosa de 2010 e da estação seca de 2011. Em cada estação os macroinvertebrados foram coletados utilizando uma rede $\mathrm{d}$ (malha de $0,250 \mathrm{~mm}$ ). Amostras de água foram coletadas para analisar Oxigênio Dissolvido, Condutividade, $\mathrm{pH}$ e Alcalinidade em laboratório. Temperatura da água, Velocidade de corrente superficial e Profundidade foram medidas em campo. Para analisar a correlação entre os fatores ambientais e a comunidade de macroinvertebrados bentônica foi utilizada a análise de Correspondência Canônica. Todos os fatores ambientais medidos mostraram variação significativa entre a estação chuvosa e seca, mostrando os efeitos da sazonalidade no ambiente do riacho. Dezoito táxons foram identificados, com Palaemonidae (Decapoda) e Chironomidae (Diptera) dominando, respectivamente, durante as estações chuvosa e seca. Os resultados mostraram que os macroinvertebrados foram mais correlacionados ao $\mathrm{pH}$, Alcalinidade e Oxigênio Dissolvido, indicando que as variações neste ecossistema são baseadas principalmente nos processo de decomposição da matéria orgânica.

Palavras-chave: insetos aquáticos; diversidade; fatores ambientais; ecossistema lótico; fauna zoobentica. 


\section{Introduction}

Water is a finite resource, with costly alternative acquisition methods such as desalinization, and the higher prevalence of waterrelated diseases are the most relevant arguments for preserving its sources, which are among the most threatened environments in the world, especially the tropical rivers located in developing countries (Baptista et al. 2000, Dudgeon et al. 2006). For these reasons, the ecological integrity of rivers and streams has become a vitally important subject regarding the management of these resources worldwide (Silveira 2004, Monteiro et al. 2008).

While many taxa contribute to biodiversity in lotic systems, benthic macroinvertebrates play central ecological roles in many systems and are among the most ubiquitous and diverse group of organisms (Rosenberg \& Resh 1993, Buss et al. 2003, Brandimarte et al. 2004, Strayer 2006, Milesi et al. 2009, Bagatini et al. 2012). Therefore, it is essential to understand the relative roles of habitat and water chemistry in structuring macroinvertebrate communities in headwaters (Nicola et al. 2010).

The abundance of stream invertebrates is known to be influenced by environmental conditions such as: hydraulic stress, temperature and water chemistry (Silveira 2004, Cummins et al. 2005, Nicola et al. 2010, Rosin et al. 2010). The dry and rainy season variation is important to determine ecological changes in the tropics (Chukwu $\&$ Nwankwo, 2004). Rainfall distribution patterns have great impact on both the chemistry of water as well as the population dynamics of the fauna (Onyema et al. 2009).

In Brazil, there are many studies on benthic macroinvertebrate communities in the Southeast (eg. Brandimarte et al. 2004, Oliveira \& Callisto 2010) and South (eg. Rosin et al. 2010, Bagatini et al. 2012) region. In the Northeast region, however, there are only a few, most of them about lentic environments (Leitão et al. 2006, Lucca et al. 2010). However in Alagoas, even basic information is lacking.

The present study analyzes the macrobenthic community of a headwater stream in a conserved Atlantic forest fragment in the state of Alagoas, during the rainy and dry seasons, and correlates the data to the environmental variables, identifying the ones that most influence the community structure.

\section{Methodology}

\section{Study area}

This study was carried out in the Salvia stream, a small water course that belongs to the Mundaú river watershed, located in Rio Largo Municipality, Alagoas. This environment is a second order stream, with a substrate mainly composed of sand. Ten sampling sites where determined along its course (Table 1).

The draining area of the Salvia stream is Mata da Sálvia, a 100 ha remnant of Atlantic forest. Its topography includes a very irregular relief, with altitude ranging between $120 \mathrm{~m}$ in elevation and $40 \mathrm{~m}$ in the valleys, and with typical native vegetation forming a canopy that filters the sunlight considerably, but also contains patches of exotic species, especially Asian bamboos. Mata da Sálvia is surrounded by sugarcane plantations, a common characteristic for small Atlantic forest fragments in Alagoas (Assis 2000). It is located in the bioclimatic zone, close to 75 biologically dry days, within the climate domain As', according to the Köppen-Geiger climate classification, with dry summers, from September to March, and rainy winters, from April to August (Assis 2000).

The stream is kept free from mostly anthropogenic impacts, as its waters are used for irrigation and human consumption. The only exception is a small water treatment plant, located near the mouth of the river, after the forest fragment delimitation.

\section{Field sampling}

The benthic macroinvertebrates were collected during the rainy and dry seasons. The period representing the end of both seasons was chosen, because during this period the invertebrates are nearly full size, thereby facilitating the sorting and identification operation, and focuses on the times when they are most tightly linked to their particular food resource (Cummins et al. 2005). The samples were taken on August 01 (sites 6 to 10), and August 02 (sites 1 to 5) of 2010 for the rainy season; on March 01 (sites 6 to 10) and March 02 (sites 1 to 5 ) of 2011 for the dry season. The macroinvertebrates were collected using a d net $(0.250 \mathrm{~mm}$ mesh $)$ to drag $2 \mathrm{~m}$ of the substrate, with two sampling units at each site, one at the margin and one in the central part of the stream. The samples were taken alive to the laboratory, where they were fixed in $70 \%$ alcohol and classified on the same day that they were collected.

Each time a biological sample was taken, Water Column Depth (cm), Superficial Current Speed (m/s; using a floater for $5 \mathrm{~m}$ ) and Water Temperature (using a mercury thermometer) were recorded. Also, water samples were collected in $500 \mathrm{ml}$ plastic bottles, for Dissolved Oxygen, $\mathrm{pH}$, Alkalinity and Conductivity. The samples were analyzed for variables at the Chemistry Laboratory of LABMAR/UFAL.

\section{Laboratory analysis}

All samples were preserved in $70 \%$ ethanol and the biological material was classified and identified under a stereoscopic microscope. The organisms were identified to Family level, except for Turbellaria, Oligochaeta and Hydracarina, using specialized literature (McCafferty 1983, Mugnai et al. 2010).

$\mathrm{T}$ test was used to evaluate the significance of the seasonal variation of the environmental variables. Canonical Correlation Analysis was used to correlate the environmental changes with the benthic macroinvertebrate community (Ter Braak \& Verdonschot 1995), run on the PAST 2.6 software (Hammer et al. 2001).

\section{Results}

The environmental factors measured indicated that the environment varied significantly in the rainy and dry seasons (Table 2). It revealed a clear temporal variation in the Salvia stream, showing that the rainy season has an environment with higher Superficial Current Speed, Dissolved Oxygen, Depth, Conductivity and $\mathrm{pH}$, but lower Alkalinity and Temperature than its dry season counterpart.

Table 1. Geographic location of the sampling sites in the Salvia stream.

\begin{tabular}{|c|c|}
\hline Site & Coordinates \\
\hline 1 & S 09' 31'02.9" and W 35 49' 54.6" \\
\hline 2 & $\mathrm{~S} 09^{\circ} 31^{\prime} 02.9^{\prime \prime}$ and W $35^{\circ} 49^{\prime} 56^{\prime \prime}$ \\
\hline 3 & $\mathrm{~S} 09^{\circ} 31^{\prime} 01.3^{\prime \prime}$ and W $35^{\circ} 49^{\prime} 55.5^{\prime \prime}$ \\
\hline 4 & $\mathrm{~S} 09^{\circ} 31^{\prime} 22.4^{\prime \prime}$ and W $35^{\circ} 49^{\prime} 34.6^{\prime \prime}$ \\
\hline 5 & $\mathrm{~S} 09^{\circ} 31^{\prime} 11.1^{\prime \prime}$ and W $35^{\circ} 50^{\prime} 05.3 "$ \\
\hline 6 & $\mathrm{~S} 09^{\circ} 31^{\prime} 27.2^{\prime \prime}$ and W $35^{\circ} 50^{\prime} 15.8^{\prime \prime}$ \\
\hline 7 & S $09^{\circ} 31^{\prime} 29.2^{\prime \prime}$ and W $35^{\circ} 50^{\prime} 21.3 "$ \\
\hline 8 & $\mathrm{~S} 09^{\circ} 31^{\prime} 33.4^{\prime \prime}$ and W $35^{\circ} 50^{\prime} 33.9^{\prime \prime}$ \\
\hline 9 & $\mathrm{~S} 09^{\circ} 31^{\prime} 38.6^{\prime \prime}$ and W $35^{\circ} 50^{\prime} 41.2^{\prime \prime}$ \\
\hline 10 & $\mathrm{~S} 10^{\circ} 32^{\prime} 16.7^{\prime \prime}$ and W $37^{\circ} 14^{\prime} 01.7^{\prime \prime}$ \\
\hline
\end{tabular}


The $\mathrm{T}$ test results for Dissolved Oxygen (T: 3,0997; P: 0,0061), Depth (T: 1,0742; P: 0,2969), Temperature (T: 1,6268; P: 0,1211), Superficial Current Speed (T: 0,7230; P: 0,4789), Alkalinity (T: 5,7767; P: 1,7863), pH (T: 3,1497; P: 0,0055) and Conductivity (T: 1,1331; P: 0,2720) show significant difference for all the measured variables.

During this study, 743 benthic macroinvertebrates were collected, divided into 18 taxa (Table 3). Chironomidae (Diptera) was the most abundant taxa, responsible for $41.05 \%$ of the specimens, followed by Palaemonidae (Decapoda), with 36.47\%, Baetidae (Ephemeroptera), $05.52 \%$, and Gomphidae (Odonata), 04.44\%.

367 individuals were collected during the rainy season, and the most abundant taxon was Palaemonidae $(67.76 \%)$. Other abundant taxa during this season were Chironomidae (09.54\%), Baetidae $(05.45 \%)$ and Gomphidae (04.90\%).

During the Dry season 376 individuals were collected and the most abundant taxon was Chironomidae (71.81\%). Other abundant taxa during this season were Palaemonidae (06.91\%), Baetidae $(05.59 \%)$ and Gomphidae (03.99\%).
The Canonical Correspondence (Figure 1) resulted in axis 1, explaining $64.30 \%$ of the variation and axis 2 explaining $15.29 \%$. $\mathrm{DO}, \mathrm{pH}$, and Alkalinity were associated with axis 1 and Depth and Conductivity was associated with axis 2 .

\section{Discussion}

The results of this study indicate that seasonality has great influence on the abiotic environment of the Salvia stream, changes that were reflected on the macrobenthic community. As indicated by the Canonical Correspondence, the benthic macroinvertebrates responded to changes on the environmental parameters of major influence, such as Dissolved Oxygen, $\mathrm{pH}$, and Alkalinity.

The main change seen in the macroinvertebrate community in the two seasons was the abundances of Palaemonidae and Chironomidae, respectively dominant taxa of rainy and dry seasons. These results indicate that the difference on the quality of the main food source available for the community is the main change in the seasons, as

Table 2. Mean and Standard Deviation of the environmental variables measured in Salvia stream during rainy (August/10) and dry (March/11) seasons.

\begin{tabular}{|c|c|c|c|c|c|c|c|c|c|c|c|c|c|c|}
\hline \multirow[t]{2}{*}{ Site } & \multicolumn{2}{|c|}{$\begin{array}{c}\text { Dissolved } \\
\text { Oxygen (mg/l) }\end{array}$} & \multicolumn{2}{|c|}{$\begin{array}{l}\text { Depth } \\
\text { (cm) }\end{array}$} & \multicolumn{2}{|c|}{$\begin{array}{c}\text { Temperature } \\
\left({ }^{\circ} \mathrm{C}\right)\end{array}$} & \multicolumn{2}{|c|}{$\begin{array}{c}\text { Surface current } \\
\text { speed }(\mathbf{m} / \mathbf{s})\end{array}$} & \multicolumn{2}{|c|}{$\begin{array}{c}\text { Alkalinity } \\
(\mathrm{mg} / \mathrm{l} \mathrm{CaCO})\end{array}$} & \multicolumn{2}{|c|}{ pH } & \multicolumn{2}{|c|}{$\begin{array}{c}\text { Conductivity } \\
(\mu \mathrm{S} / \mathrm{cm})\end{array}$} \\
\hline & Rainy & Dry & Rainy & Dry & Rainy & Dry & Rainy & Dry & Rainy & Dry & Rainy & Dry & Rainy & Dry \\
\hline Mean & 7.21 & 6.85 & 28.90 & 24.07 & 25.83 & 26.05 & 0.37 & 0.33 & 1.36 & 2.75 & 7.21 & 6.83 & 59.38 & 56.72 \\
\hline $\begin{array}{l}\text { Standard } \\
\text { deviation }\end{array}$ & 0.19 & 0.31 & 12.43 & 6.90 & 0.25 & 0.35 & 0.19 & 0.31 & 0.14 & 0.15 & 0.43 & 0.62 & 0.19 & 0.33 \\
\hline
\end{tabular}

Table 3. Abundance (No) and relative abundance (\%) of the taxa collected on Salvia stream during rainy (June/10 to August/10) and dry (January/11 to March/11) seasons.

\begin{tabular}{|c|c|c|c|c|c|c|}
\hline \multirow{2}{*}{ Taxa } & \multicolumn{2}{|c|}{ Rainy Season } & \multicolumn{2}{|c|}{ Dry Season } & \multicolumn{2}{|c|}{ Total } \\
\hline & No & $\%$ & No & $\%$ & No & $\%$ \\
\hline Turbellaria & 2 & 0.54 & 3 & 0.80 & 5 & 0.67 \\
\hline Oligochaeta & 3 & 0.82 & 2 & 0.53 & 5 & 0.67 \\
\hline Hydracarina & 2 & 0.54 & 3 & 0.80 & 5 & 0.67 \\
\hline Decapoda & - & - & - & - & - & - \\
\hline Palaemonidae & 245 & 66.76 & 26 & 6.93 & 271 & 36.47 \\
\hline Odonata & - & - & - & - & - & - \\
\hline Caenagrionidae & 4 & 1.09 & 1 & 0.27 & 8 & 1.08 \\
\hline Calopterigidae & 8 & 2.18 & 0 & 0.00 & 5 & 0.67 \\
\hline Corduliidae & 4 & 1.09 & 10 & 2.67 & 14 & 1.88 \\
\hline Gomphidae & 18 & 4.90 & 15 & 4.00 & 33 & 4.44 \\
\hline Libellulidae & 0 & 0.00 & 3 & 0.80 & 3 & 0.40 \\
\hline Hemiptera & - & - & - & - & - & - \\
\hline Corixidae & 0 & 0.00 & 1 & 0.27 & 1 & 0.13 \\
\hline Mesoveliidae & 2 & 0.54 & 0 & 0.00 & 2 & 0.27 \\
\hline Ephemeroptera & - & - & - & - & - & - \\
\hline Baetidae & 20 & 5.45 & 21 & 5.60 & 41 & 5.52 \\
\hline Leptophlebiidae & 12 & 3.27 & 8 & 2.13 & 20 & 2.69 \\
\hline Trichoptera & - & - & - & - & - & - \\
\hline Helicopsychidae & 8 & 2.18 & 1 & 0.27 & 9 & 1.21 \\
\hline Diptera & - & - & - & - & - & - \\
\hline Chironomidae & 35 & 9.54 & 270 & 72.00 & 305 & 41.05 \\
\hline Tipulidae & 2 & 0.54 & 7 & 1.87 & 9 & 1.21 \\
\hline Coleoptera & - & - & - & - & - & - \\
\hline Elmidae & 2 & 0.54 & 4 & 1.07 & 6 & 0.81 \\
\hline Hebridae & 0 & 0.00 & 1 & 0.27 & 1 & 0.13 \\
\hline Total & 367 & 100.00 & 375 & 100.00 & 743 & 100.00 \\
\hline
\end{tabular}



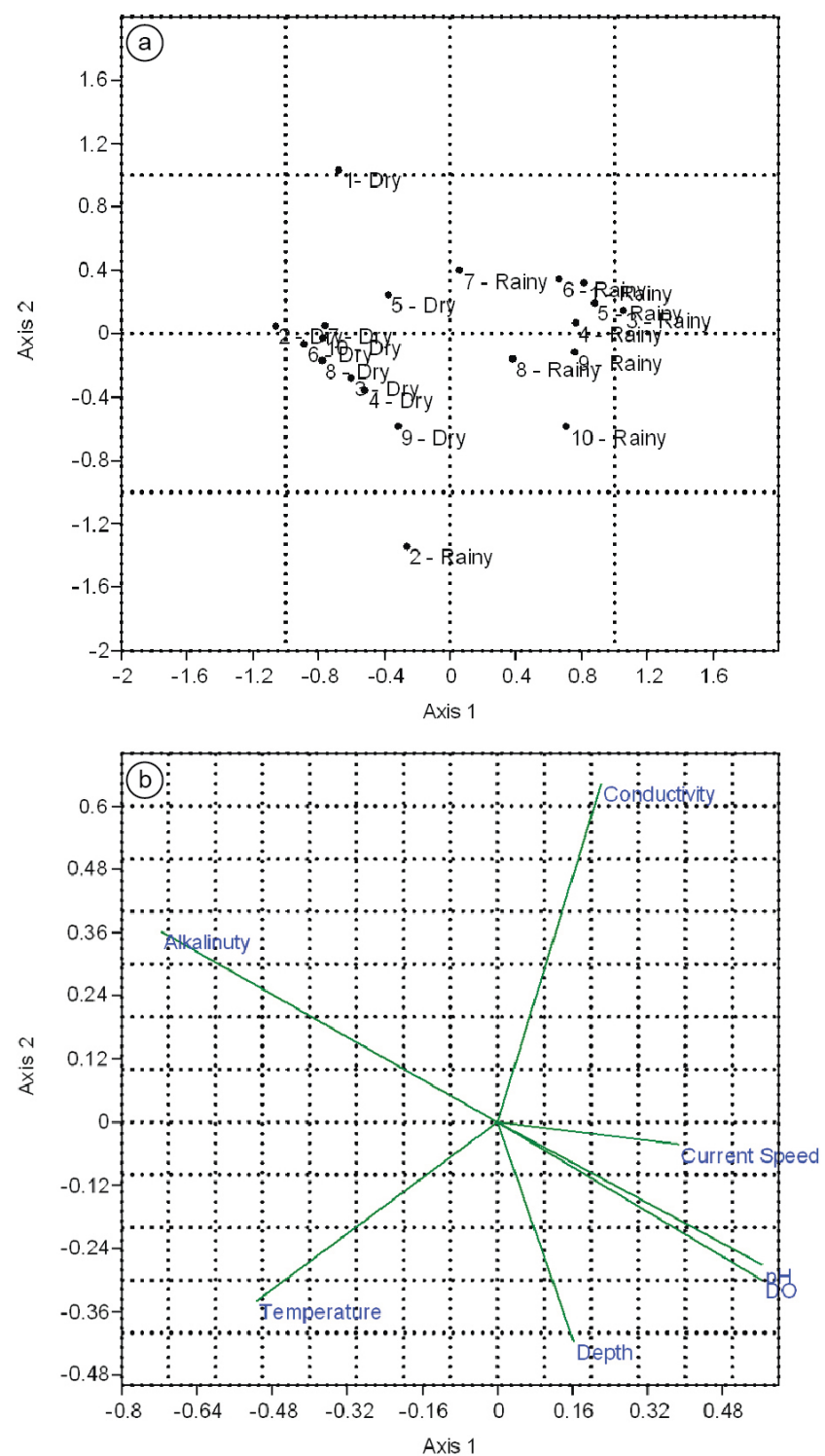

Figure 1. Results of Canonical Correspondence. a: Distribution of sites, considering both seasons. b: Plotting of environmental factors.

Palaemonidae and Chironomidae are associated to different food sources (Cummins et al. 2005).

The fact that most of the macroinvertebrates collected are associated to particulate organic matter shows that the macrobenthic community in Salvia stream is mainly composedof taxa heavily dependent on the riparian vegetation as primary food source. This is expected to a low order stream that drains a forested area, as allocthonous organic matter, mainly leaves from riparian vegetation, is a major energy source of low order woodland streams with welldeveloped riparian corridors (Benfield 1997, Wallace et al. 1997, Cummins et al. 2005, Tomanova et al. 2006, Clarke et al. 2008, Uwadiae 2010).

This dependence derives from the very low primary production, which is a characteristic of forested low order streams, due to shading caused by the riparian vegetation (Vannote et al. 1980, Wallace et al. 1999, Allan \& Castillo 2007). In Salvia stream this was reinforced by the non-consolidate nature of the substrate, which does not allow the attachment of algae. Taxa associated to this food source, such as Gastropoda and Corixidae, were very rare or absent.
The canonical correlation analysis showed the influence of water chemistry on the macroinvertebrate community, as aquatic chemistry variables are frequently used to explain variation in benthic communities (Nicola et al. 2010). Alkalinity, pH and Dissolved Oxygen were shown as the most important environmental factors, as they were associated to the decomposition of organic matter. Shimabukuro \& Henry (2011) found that lower pH and Dissolved Oxygen are derived from ions released during leaf decomposition.

Therefore the results suggest a difference on the quality of the particulate organic matter between the two sampling periods, which seem to follow a seasonal pattern. During the Rainy season the superficial runoff carries residues that accumulate in the stream, forming coarse particulate organic matter which is the primary food source for Palaemonidae, the dominant taxon. In the following Dry season the shredded organic matter is further processed by bacterial decomposition, thus liberating the fine particulate organic matter into the system, which is the main food resource of the dominant taxa of this season, Chironomidae and Baetidae. Thus the water flow and temperature influences the amount of available food, promoting the release and removal of nutrients (Oliveira \& Nessimian 2010).

Of the taxa collected in this study, aquatic insects were the most abundant, corresponding to 14 of the 18 taxa sampled. Insecta represent one of the most important groups of invertebrates that comprise the benthic fauna, especially due to its abundance and diversity (Higuti et al. 1993). The water quality and ecological health of Salvia stream is confirmed by the presence of five families of Odonata sampled in this study, as specialized feeders are more sensitive and thought to be well represented in healthy streams (Uwadiae 2010).

\section{Conclusion}

This study supplemented information on the structure of benthic communities, contributing to narrowing the gap in studies of this nature in the region. Further research on the remaining preserved environmental areas is needed to determine whether the local and seasonal patterns that characterize the benthic macroinvertebrates in the Salvia stream are determining factors at a regional level.

\section{References}

ALLAN, J.D. \& CASTILLO, M.M. 2007. Stream ecology: Structure and function of running waters. Springer, Dordrecht. http://dx.doi. org/10.1007/978-1-4020-5583-6

ASSIS, J.S. 2000. Biogeografia e conservação da biodiversidade - projeções para Alagoas. Catavento, Maceió.

BAGATINI, Y.M., DELARIVA, R.L. \& HIGUTI, J. 2012. Benthic macroinvertebrate community structure in a stream of the north-west region of Paraná State, Brazil. Biota Neotrop. 12:307-317. http://dx.doi. org/10.1590/S1676-06032012000100023

BAPTISTA, D.F., BUSS, D.F., DROVILLÉ, L.F.M. \& NESSIMIAN, J.L. 2000. Diversity and habitat preference of aquatic insects along the longitudinal gradient of the Macaé river basin, Rio de Janeiro, Brazil. Rev. Bras. Biol. 61:249-258.

BENFIELD, E.F. 1997. Comparison of litterfall input to streams. In Webster, J.R \& Meyer. J.L. Stream organic matter budgets. J. N. Am. Benthol. Soc. 16:104-108. http://dx.doi.org/10.2307/1468242

BRANDIMARTE, A.L., SHIMIZU, G.Y., ANAYA, A.M. \& KUHLMANN, M.L. 2004. Amostragem de invertebrados bentônicos. In Amostragem em Limnologia (C.E.M. Bicudo \& D.C. Bicudo). Editora UFSCar, São Carlos.

BUSS, D.F., BAPTISTA, D.F. \& NESSIMIAN, J.L. 2003. Bases conceituais para a aplicação de biomonitoramento em programas de avaliação da qualidade da água de rios. Cad. Saúde Pública. 19:465-473. PMid:12764462. http://dx.doi.org/10.1590/S0102-311X2003000200013 
CHUKWU, I.O. \& NWANKWO, D.I. 2004. The impact of Land based pollution on the hydrochemistry and macrobenthic community of a tropical West African creek. Ekologia. 2:1-9.

ClARKe, A., McNAlly, R., BOND, N. \& LAKE, P.S. 2008. Macroinvertebrate diversity in headwater streams: a review. Freshw. Biol. 53:1707-1721. http://dx.doi.org/10.1111/j.1365-2427.2008.02041.x

CUMMINS, K.W., MERRITT, R.W. \& ANDRADE, P.C.N. 2005. The use of macroinvertebrate functional groups to characterize ecosystem attributes in selected streams and rivers in south Brazil. Stud. Neotrop. Fauna E. 40:69-89. http://dx.doi.org/10.1080/01650520400025720

DUDGEON, D., ARTHINTGTON, A.H., GESSNER, M.O., KAWABATA, Z., KNOWLER, D.J., LEVEQUE, C., NAIMAN, R.J., PRIEUR-RICHARD, A., SOTO, D., STIANISSNY, M.L.J. \& SULLIVAN, C.A. 2006. Freshwater Biodiversity: importance, threats, status and conservation challenges. Biol. Rev. 81:163-182. PMid:16336747. http://dx.doi. org $/ 10.1017 / \mathrm{S} 1464793105006950$

HAMMER, Ø., HARPER, D.A.T. \& RYAN, P.D. 2001. Past: Paleontological Statistics Software Package for Education and Data Analysis. Palaeontol. Electron. 4(1).

HIGUTI, J., TAKEDA, A.M. \& PAGGI, A.C. 1993. Distribuição espacial das larvas de Chironomidae (Insecta, Diptera) do rio Baía (MS-Brasil). UNIMAR.15:65-81.

LEITÃO, A.C., FREIRE, R.H.F., ROCHA, O. \& SANTAELLA, S.T. 2006. Zooplankton community composition and abundance of two Brazilian semiarid reservoirs. Acta Limnol. Bras. 18:451-468.

LUCCA, J.V., PAMPLIN, P.A.Z., GESSNER, A.F., TRIVINHOSTRIXINO, S., SPADANO ALBUQUERQUE, A.L. \& ROCHA, O. 2010. Benthic macroinvertebrates of a tropical lake: Lake Caçó, MA, Brazil. Braz. J. Biol. 70:593-600.

McCAFFERTY, W.P. 1983. Aquatic entomology: the fisherman's and ecologists' illustrated guide to insects and their relatives. Jones and Bartllet Publishers, Boston.

MILESI, S.V., BIASI, C., RESTELLO, R.M. \& HEPP, L.U. 2009. Distribution of benthic macroinvertebrates in subtropical streams (Rio Grande do Sul, Brazil). Acta Limnol. Bras. 21:419-429.

MONTEIRO, T.R., OLIVEIRA, L.G. \& GODOY, B.S. 2008. Biomonitoramento da qualidade de água utilizando macroinvertebrados bentônicos: adaptacão do índice biótico BMWP' à bacia do rio Meia Ponte-GO. Oecol. Bras. 12:553-563.

MUGNAI, R., NESSIMIAN, J.L. \&. BAPTISTA, D.F. 2010. Manual de identificação dos macroinvertebrados aquáticos do estado do Rio de Janeiro. Technical Books, Rio de Janeiro.

NICOLA, G.G., ALMODÓVAR, A. \& ELVIRA, B., 2010. Effects of environmental factors and predation on benthic communities in headwater streams. Aquat. Sci. 72:419-429. http://dx.doi.org/10.1007/s00027-010$0145-8$
OLIVEIRA, A. \& CALLISTO, M. 2010. Benthic macroinvertebrates as bioindicators of water quality in na Atlantic forest fragment. Iheringia, Sér. Zool. 100:291-300.

OLIVEIRA, A.L.H. \& NESSIMIAN, J.L. 2010. Spatial distribution and functional feeding groups of aquatic insect communities in Serra da Bocaina streams, southeastern Brazil. Acta Limnol. Bras. 22:424-441. http://dx.doi.org/10.4322/actalb.2011.007

ONYEMA, I.C., LAWAL-ARE, A.O., AKINREMI, T.A. \& BASSEY, O.B. 2009. Water Quality, Parameters, Chlorophyll a and Zooplankton of an Estuarine Creek in Lagos. J. Am. Scie. 5:76-94.

ROSIN, G.R., MARGAROTTI, D.P.O. \& TAKEDA, A.M. 2010. Chironomidae (Diptera) community structure in two subsystems with different states of conservation in a floodplain of southern Brazil. Acta Limnol. Bras. 22:276-286. http://dx.doi.org/10.4322/actalb.02203004

ROSENBERG, D.M. \& RESH, V.H. 1993. Introduction to freshwater biomonitoring and benthic macroinvertebrates. In Freshwater biomonitoring and benthic macroinvertebrates (D.M. Rosemberg, V.H. Resh). Chapman \& Hall, Nova York.

SHIMABUKURO, E.M. \& HENRY, R. 2011. Controlling factors of benthic macroinvertebrates distribution in a small tropical pond, lateral to the Paranapanema River (São Paulo, Brazil). Acta Limnol. Bras. 26:154-163. http://dx.doi.org/10.1590/S2179-975X2011000200006

SILVEIRA, M.P. 2004. Aplicação do biomonitoramento para avaliação da qualidade da água em rios. Embrapa - Meio Ambiente, Jaguariúna.

STRAYER, D.L. 2006. Challenges for freshwater invertebrate conservation. J. N. Am. Benthol. Soc. 25:271-287. http://dx.doi.org/10.1899/08873593(2006)25[271:CFFIC]2.0.CO;2

TOMANOVA, S., GOITIA, E. \& HELESIC, J. 2006. Trophic levels and functional feeding groups of maroinvertebrates in neotropical streams. Hydrobiologia 556:251-264. http://dx.doi.org/10.1007/s10750-0051255-5

TER BRAAK, C.J.F. \& VERDONSCHOT, P.F.M. 1995. Canonical Correspondence Analysis and Related Multivariate Methods in Aquatic Ecology. Aquat. Sci. 57:255-289. http://dx.doi.org/10.1007/BF00877430

UWADIAE, R.E. 2010. Macroinvertebrates functional feeding groups as indices of biological assessment in a tropical aquatic ecosystem: implications for ecosystem functions. New York Sci. J. 3:6-15.

VANNOTE, R.L., MINSHALL, G.W., CUMMINS, K.W. SEDELL, J.R. \& CUSHING, C.E. 1980. The river continuum concept. Can. J. Fish. Aquat. Sci. 37:130-137. http://dx.doi.org/10.1139/f80-017

WALLACE, J.B., EGGERT, S.L., MEYER, J.L. \& WEBSTER, J.R. 1997. Multiple trophic levels of a forest stream linked to terrestrial litter inputs. Science. 277:102-104. http://dx.doi.org/10.1126/science.277.5322.102

WALLACE, J.B., EGGERT, S.L., MEYER, J.L. \& WEBSTER, J.R. 1999. Effects of resource limitation on a detrital-based ecosystem. Ecol. Monogr. 69:409-442. http://dx.doi.org/10.1890/0012-9615(1999)069[0409:EOR LOA]2.0.CO;2 